\title{
PASAR UANG SYARIAH
}

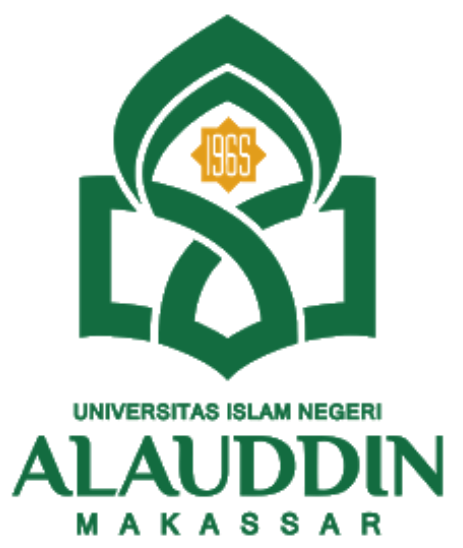

MAKALAH

Disusun Untuk Memenuhi Tugas Revisi Makalah Kelompok Mata Kuliah Ekonomi Moneter Islam Program Studi Perbankan Syariah Semester 5 Tahun 2021

\section{Oleh:}

Safitry (90500119065)

Novira Putri Arlianti (90500119072)

Rezky Aditya (90500119080)

\section{Dosen Pengajar:}

SAMSUL ARIFAI, S.A.B, M.A

\section{PROGRAM STUDI PERBANKAN SYARIAH FAKULTAS EKONOMI DAN BISNIS ISLAM UIN ALAUDDIN MAKASSAR}




\section{KATA PENGANTAR}

Puji syukur kehadirat Allah SWT. yang telah memberikan segala berkah, taufiq dan bimbingannya untuk menyelesaikan tugas revisi makalah berjudul “Pasar Uang Syariah”.

Shalawat dan salam kepada junjungan kita Nabi Muhammad SAW tercinta, yang memimpin kita dari jaman kegelapan ke jaman terang.

Kami berharap makalah ini dapat membantu pembaca memahami dan mempelajari lebih lanjut tentang pasar uang syariah. Sebagai penulis, kami memahami bahwa masih banyak kesalahan dan kekurangan dalam penulisan artikel ini. Oleh karena itu, sebagai penulis, kami mengharapkan dan menerima segala bentuk saran dan kritik dari para pembaca kami yang dapat membantu kami memperbaiki dan mempromosikan artikel-artikel selanjutnya.

Makassar, Desember 2021

Kelompok 4 


\section{DAFTAR ISI}

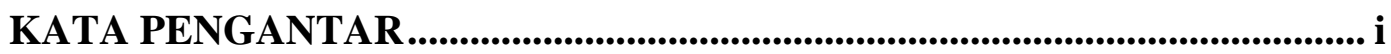

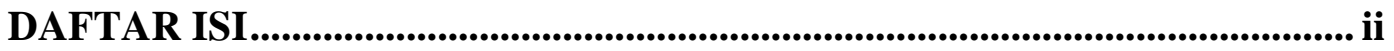

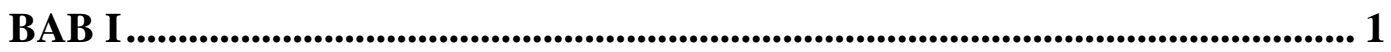

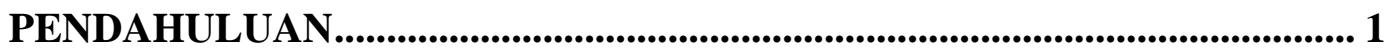

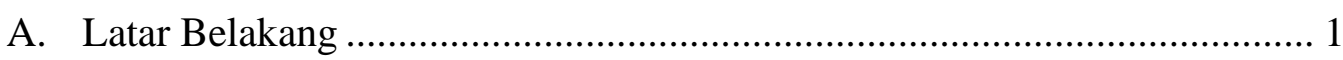

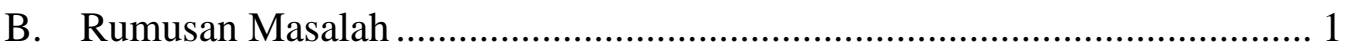

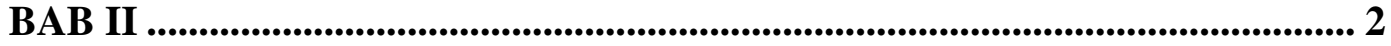

PEMBAHASAN ............................................................................................... 2

A. Perbedaan Pasar Uang dan Pasar Modal ....................................................... 2

B. Fungsi, Peserta dan Tujuan Pasar Uang ..................................................... 4

C. Instrumen Pasar Uang di Indonesia ........................................................... 6

D. Pasar Uang Antar Bank Berdasarkan Prinsip Syariah ............................... 8

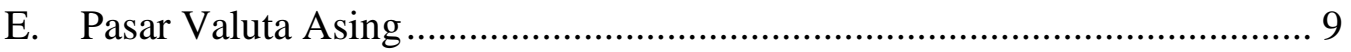

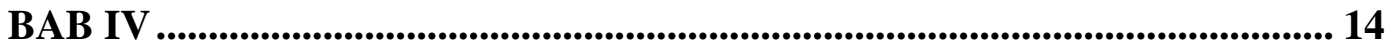

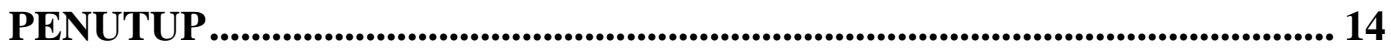

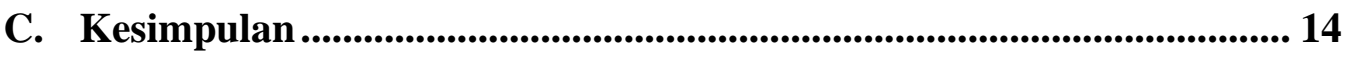

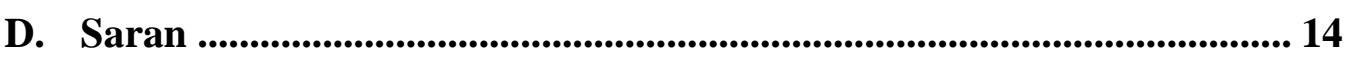

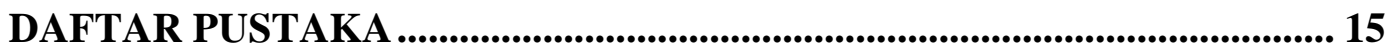




\section{BAB I \\ PENDAHULUAN}

\section{A. Latar Belakang}

Investasi modal diperlukan. Ini disebut investasi karena menunda konsumsi saat ini untuk mendapatkan konsumsi masa depan. Pada dasarnya, investasi melibatkan menginvestasikan uang (modal) dalam berbagai alternatif aset, yang diharapkan memberikan hasil dalam bentuk pengembalian. Namun, tidak semua investasi selalu menghasilkan pengembalian yang diharapkan. Karena berinvestasi selalu melibatkan ketidakpastian dan risiko, dan terkadang tidak dapat dihindari.

Pada dasarnya, investasi dapat dibagi menjadi dua jenis investasi. Pertama, aset riil juga disebut investasi langsung. Aset riil adalah investasi yang dilakukan dalam bentuk barang modal seperti tanah, bangunan, emas, mesin, dan perusahaan. Kedua, aset keuangan yang biasa disebut sebagai investasi tidak langsung. Investasi dalam bentuk saham, obligasi, surat berharga, dan deposito.

\section{B. Rumusan Masalah}

1. Bagaimana perbedaan pasar uang dan pasar modal?

2. Bagaimana fungsi, peserta, dan tujuan pasar uang?

3. Bagaimana instrument pasar uang di Indonesia (Konvensional \& Islam)?

4. Bagaimana pasar uang antar bank berdasarkan prinsip syariah?

5. Bagaimana pasar valuta asing? 


\section{BAB II \\ PEMBAHASAN}

\section{A. Perbedaan Pasar Uang dan Pasar Modal}

Pasar uang adalah tempat bertemunya pihak yang surplus dan pihak yang kekurangan, dan dananya bersifat jangka pendek, yaitu jatuh temponya kurang dari setahun. Melayani banyak pihak seperti pemerintah, bank, perusahaan asuransi dan lembaga keuangan lainnya. Pasar uang ini menguntungkan mereka yang tidak memiliki uang, sementara mereka yang memiliki uang banyak mendapat keuntungan dari kesempatan untuk meningkatkan pendapatan mereka sekaligus mengurangi risiko keuangan.

Pasar uang berbeda dari pasar modal dalam hal transaksi dilakukan melalui pertukaran atau Stock Exchange. Pasar uang bersifat abstrak dan tidak ada yang istimewa darinya. Sebab, dalam kasus pasar modal, transaksi di pasar uang dilakukan secara independent OTC (Over the Counter Market), Setiap pesertanya melakukan ini baik melalui desktop masing-masing peserta atau di ruang transaksi. Pasar keuangan tidak lagi terbatas pada wilayah satu negara. Dengan pesatnya perkembangan perdagangan global, dana bergerak ke seluruh dunia untuk menemukan investasi yang menawarkan pengembalian yang diharapkan tertinggi untuk tingkat risiko tertentu. Begitu juga dalam pertumbuhan perdagangan internasional yang memerlukan pasar uang dan juga pasar modal. ${ }^{1}$

Pasar uang dan pasar modal merupakan wahana investasi bagi investor. Pasar keuangan jangka pendek memiliki karakteristik tertentu yang membedakannya dari pasar modal dalam hal berapa lama komoditas diperdagangkan, di mana dijual, dan di mana dijual kepada penjual dan pembeli. Perbedaannya adalah:

1) Alat untuk dijual

Dana untuk penempatan dan peminjaman dana di pasar uang jangka pendek bersifat jangka pendek (kurang dari satu tahun) dan memiliki likuiditas dasar. Di

\footnotetext{
${ }^{1}$ Evan Hamzah Muchtar and Siti Najma, 'APLIKASI SISTEM KEUANGAN SYARIAH PADA PASAR UANG’, Asy-Syukriyyah, 20 (2019), 56.
} 
sisi lain, produk yang diperdagangkan di pasar modal adalah surat berharga jangka panjang, yaitu adalah dana permanen atau semi permanen.

2) Pasar tempat perdagangan berlangsung

Pasar modal mempunyai tempat perdagangan tertentu biasa disebut bursa efek. Sebaliknya, di pasar uang yang transaksinya bersifat abstrak, artinya perdagangan tidak dilakukan di pasar tertentu.

3) Struktur organisasi

Di pasar modal, karena terdapat tempat khusus untuk berdagang, maka struktur organisasinya lebih tertata dan pelaksanaannya juga diatur dan diawasi oleh badan pengelola pasar modal. Berbeda dengan pasar uang yang tidak terorganisir.

4) Untuk tujuan mengeluarkan surat-surat berharga dari penjual atau pihak.

Pasar uang jangka pendek dirancang agar terpenuhi kebutuhan modal jangka pendek, seperti kebutuhan modal kerja, lain halnya pasar modal lebih bertujuan investasi atau ekspansi perusahaan. Bagi investor, membeli sekuritas di pasar keuangan jangka pendek dapat menghasilkan keuntungan, tetapi di pasar modal, selain menghasilkan keuntungan, Anda juga dapat mengendalikan perusahaan.

Di sisi lain, ada beberapa perbedaan antara pasar uang dan pasar modal dalam kegiatan ekonomi:

1. Di pasar keuangan jangka pendek, terdapat produk-produk seperti SBI, tabungan, deposito, dan surat berharga yang berjangka pendek sekitar satu tahun. Sedangkan di pasar modal, produk-produk seperti obligasi, reksa dana, dan saham memiliki daya tahan yang tinggi.

2. Otoritas tertinggi di pasar uang adalah Bank Indonesia (BI), dan pasar modal adalah Kementerian Keuangan.

3. Di pasar modal terdapat pasar sekunder yang berfungsi pelengkap, sedangkan pada pasar keuangan jangka pendek tidak terdapat pasar sekunder walaupun hanya sebagian kecil. 
4. Operasi di pasar keuangan jangka pendek terjadi antar bank dan operasi di pasar modal dilakukan di bursa efek.

5. Produk keuangan derivatif di pasar modal adalah opsi, hak, dan waran, berbeda dengan produk keuangan derivatif di pasar keuangan jangka pendek hanya reksa dana.

6. Profitabilitas dan risiko pasar modal lebih tinggi daripada pasar keuangan jangka pendek. ${ }^{2}$

\section{B. Fungsi, Peserta dan Tujuan Pasar Uang}

Fungsi pasar uang yang erat kaitannya dengan perbankan dan sistem moneter adalah fungsi likuiditas, bidang sosialisasi kebijakan, dan fungsi informasi.

1. Menjadi mekanisme alternatif, khususnya dalam konteks lembaga keuangan dan 4.444 peserta lainnya yang memenuhi kebutuhan pendanaan jangka pendek dan mengalokasikan dana untuk ekses likuiditas.

2. Sebagai sarana pengendalian moneter tidak langsung oleh otoritas moneter di negara pasar terbuka seperti Indonesia, transaksi pasar terbuka Bank Indonesia dilakukan melalui pasar uang dengan menggunakan sertifikat Bank Indonesia (SBI), dan Surat Berharga Pasar Keuangan (SBPU) sebagai Instrumen Keuangan

3. Dalam hal kemampuan informasi, pasar keuangan jangka pendek menyediakan perusahaan, pemerintah, individu, sektor asing dan pelaku pasar jangka pendek lainnya dengan informasi tentang kondisi moneter, preferensi dan perilaku dari pelaku pasar keuangan jangka pendek, dampak dan interaksi kebijakan moneter kasus kegiatan ekonomi dalam dan luar negeri. ${ }^{3}$

Ada dua pihak yang terlibat dalam pasar uang, secara langsung dan tidak langsung. Kedua belah pihak memiliki kepentingan dan tujuan mereka sendiri untuk satu sama lain. Pihak-pihak berikut berpartisipasi dalam pasar uang:

${ }^{2}$ Yenni Samri Julia Nasution, Pasar Uang Dan Pasar Modal : Suatu Pengantar, 2018.

${ }^{3}$ Ismawati, 'PASAR UANG DALAM PERSPEKTIF ISLAM', Manajemen Ide Dan Inspirasi, 3.1, 96-106. 
1. Kedua belah pihak yang membutuhkan dana, baik bank maupun perusahaan non-perbankan, butuh dana yang perlu segera diisi kembali untuk kepentingan tertentu.

2. 2. Pihak yang menginvestasikan dana, yaitu pihak yang menyediakan dana untuk tujuan investasi di pasar uang atau pihak yang menjual dana (baik bank maupun perusahaan non-perbankan).

Orang yang membutuhkan dana dan tujuan mereka yang mencari dana ini di pasar keuangan jangka pendek bergantung pada minat dan kebutuhan mereka yang mencarinya. Berikut ada empat tujuan untuk mengumpulkan uang di pasar uang jangka pendek:
a) Melengkapi keperluan jangka pendek,
b) Melengkapi keperluan likuiditas,
c) Melengkapi keperluan tabungan kerja,
d) Biaya likuidasi yang harus segera dibayar

Tujuan berinvestasi di pasar modal pemangku kepentingan adalah untuk:

1. Mendapatkan pendapatan atas tingkat suku bunga tertentu,

2. Menolong pihak yang sangat membutuhkan,

3. Membayangkan dengan harapan bisa mendapat keuntungan yang besar dalam waktu singkat dalam keadaan ekonomi tertentu. ${ }^{4}$

Pelaku pasar uang terdiri dari:
a. Bank
b. Yayasan
c. Dana Pensiunan
d. Perusahaan Asuransi
e. Perusahaan-perusahaan besar
f. Lembaga Pemerintahan

\footnotetext{
${ }^{4}$ Mia Lasmi Wardiyah, Manajemen Pasar Uang \& Pasar Modal (Bandung, 2011).
} 


\author{
g. Lembaga Keuangan Lainnya \\ h. Individu (masyarakat)
}

\title{
C. Instrumen Pasar Uang di Indonesia
}

\section{Konvensional}

\section{Sertifikat Bank Indonesia (SBI)}

Surat utang yang diterbitkan oleh Bank Indonesia untuk dieksekusi dengan jumlah tertentu yang jatuh tempo kepada pemegangnya pada tanggal tertentu. Produk ini memiliki masa kadaluarsa tidak lebih dari 1 tahun.

\section{Surat Berharga Pasar Uang (SBPU)}

Surat berharga jangka pendek yang dapat diperdagangkan secara diskonto di Bank Indonesia atau agen diskonto yang ditunjuk oleh BI.

\section{Sertifikat Deposito}

Instrumen keuangan yang diterbitkan oleh bank pada saat kedatangan ditandai dengan jumlah, periode, dan tingkat bunga tertentu. Bukti Setoran adalah deposito berjangka yang memungkinkan Anda untuk menjual Bukti Setoran. Fitur pembeda terbesar dari deposito berjangka adalah bahwa mereka dapat ditransfer atau dijual melalui lembaga keuangan lain sebelum jatuh tempo.

\section{Comercial Paper}

Bill of exchange tanpa jaminan diterbitkan oleh perusahaan untuk memperoleh dana jangka pendek dan dijual kepada investor di pasar uang jangka pendek.

\section{Call Money}

Meminjam dana secara jangka pendek dari satu bank ke bank lain

\section{Repurchase Agreement}

Jual menjual surat berharga dengan perjanjian (sebelumnya) pihak yang menjual akan kmebali memnbeli sesuai perjanjian diawal.

\section{Banker's Acceptence}


Alat pasar uang yang digunakan untuk memberikan kredit kepada eksportir atau importir untuk membayar barang tertentu atau membeli mata uang asing. ${ }^{5}$

\section{Islam}

Aplikasi sistem keuangan syariah syariah pada pasar uang terdapat dalam instrumen pasar uang syariah, diantaranya:

a. Sertifikat Bank Indonesia Syariah (SBIS)

Berdasarkan prinsip Syariah dalam mata uang rupiah, merupakan surat berharga jangka pendek yang diterbitkan oleh Bank Indonesia.

b. Repurchase Agreement (Repo) SBIS

Transaksi pinjaman diperpanjang dari BUS Bank Indonesia atau UUS ke agunan GBU (secured borrowing), dalam hal ini kepemilikan surat berharga di tempat penyimpanan tetap berada di tangan penjual.

\section{c. Surat Berharga Syariah Negara (SBSN)}

Surat Berharga Negara yang diterbitkan berdasarkan prinsip Syariah sebagai bukti bunga atas aset SBSN menggunakan mata uang rupiah ataupun valuta asing.

\section{d. Repurchase Agrement (Repo) SBSN}

SBSN menjual kepada Bank Indonesia yang telah melakukan repurchase agreement dengan harga yang disepakati dan jangka waktu pemenuhan syariah.

e. Pasar Uang Antarbank Syariah (PUAS)

Jual beli keuangan antar bank jangka pendek ini berdasarkan prinsip syariah baik dalam rupiah maupun valuta asing. Instrumen yang digunakan pelaku pasar dalam perdagangan Puas adalah Sertifikat Investasi Mudarava Antar Bank (SIMA) dan Prinsip Syariah Antar Bank berdasarkan Sertifikat Transaksi Komoditas (Sika). SIMA merupakan Produk Pasar Uang Antar Bank (Puas) berbasis Syariah. Sika

\footnotetext{
${ }^{5}$ Bambang Prishardoyo, 'Analisis Faktor-Faktor Yang Mempengaruhi Volume Transaksi Pasar Uang Antar Bank Di Indonesia Tahun 1983-2007', Jejak, 3.2 (2010), 123-31 <https://doi.org/10.15294/jejak.v3i2.4655>
} 
adalah sertifikat yang diterbitkan sesuai dengan hukum Syariah di bus atau UUS dalam transaksi Puas, bukti jual beli dengan pembayaran ditangguhkan untuk transaksi komoditas di bursa. ${ }^{6}$

\section{Pasar Uang Antar Bank Berdasarkan Prinsip Syariah}

Pasar uang antar bank yang diperbolehkan dalam syariah adalah yang transaksinya tidak berbunga karena menghasilkan pendapatan bunga tidak tersedia dalam ilmu ekonomi. Muslim, orang yang begitu likuid, akan dihadapkan pada pilihan apakah akan mengambil risiko dan menyimpannya secara tunai tanpa menghasilkan keuntungan, atau mengambil risiko dengan berbagi risiko dan menginvestasikan uang mereka dalam aset bagi hasil. mendapat untung Dalam ekonomi Islam, tingkat pengembalian berbeda dan tingkat bunga tidak ditentukan sebelumnya. Satu-satunya hal yang dapat Anda ketahui sebelumnya adalah rasio bagi hasil. ${ }^{7}$

Akad-akad yang dianjurkan adalah mudharabah, musyarakah, qard, wadiah, maupun sharf, dan kepemilikinya hanya dapat dipindahtangankan sekali. Namun yang terlihat hanya menggunakan dua akad yaitu wadi'ah dan mudharabah. Ini dikarenakan di bank syariah, alat yang disediakan oleh pasar uang adalah IMA (Sertifikat Investasi Mudharabah Antar Bank), SBPU (Surat Berharga Pasar Uang) Mudharabah dan SWBI (Sertifikat Wadi'ah Bank Indonesia).

Melalui pengoperasian Pasar Uang Antar Bank Syariah, semua bank umum, termasuk Bank Syariah, dapat menyimpan dana dalam bentuk Interbank Investment Certificate (IMA) yang diterbitkan oleh bank syariah dengan likuiditas yang sulit. Saat Anda membeli IMA, Anda membayar pengembalian investasi atau pinjaman Anda saat IMA kedaluwarsa. Dengan demikian, bank yang membeli bagi hasil menerima bagi hasil, bukan bunga (Tim Pengembangan Perbankan Syariah IBI, 2001: 276). Faktanya, produk yang diperdagangkan di

\footnotetext{
${ }^{6}$ Muchtar and Najma.

${ }^{7}$ Samsul Samsul, Najamuddin Mara Hamid, and Hotman Guba Nasution, 'Sistem Pengendalian Inflasi Dalam Sistem Ekonomi Islam', Al-Azhar Journal of Islamic Economics, 1.1 (2019), 16-28 <https://doi.org/10.37146/ajie.v1i1.10>.
} 
pasar mata uang berbasis Syariah berada pada tahap 1 (sekuritisasi level 1), dan produk ini menjadi turunan melalui 'sekuritisasi ulang (sekuritisasi level 2)' yang disepakati para ilmuwan. Tidak bisa berdagang.

Fatwa Dewan Syariah Nasional No. Alasan adanya 37 adalah bahwa penggunaan bunga tidak diperbolehkan di pasar uang antar bank berbasis syariah:

Pertama: Mudharabah, yaitu pihak utama (malik, shahib almaal) menyediakan semua modal dan pihak sekunder (amil, mudharib, pelanggan) bertindak sebagai pengelola dan mendistribusikan kepentingan bisnis di antara mereka, sesuai dengan kesepakatan yang diatur dalam Perjanjian Perjanjian Kerjasama Bisnis antara kedua belah pihak.

Kedua: Musyarakah adalah perjanjian kerjasama antara dua pihak atau lebih untuk suatu usaha tertentu, di mana masing-masing pihak memberikan kontribusi dana (modal), di mana manfaat dan risiko dibagi.

Ketiga: Al-Qardh adalah akad keuangan dengan nasabah tertentu dengan syarat lembaga keuangan syariah dan nasabah harus mengembalikan dana yang diterima nasabah kepada lembaga keuangan syariah dalam jangka waktu yang disepakati nasabah. Untuk satu orang untuk mempercayakan orang lain dengan perlindungan yang memadai (seperti kebiasaan) Kelima: al-Sharf (perdagangan mata uang asing). ${ }^{8}$

\section{E. Pasar Valuta Asing}

Pasar valuta asing atau valuta asing didefinisikan sebagai tempat, sistem di mana individu, perusahaan dan bank dapat melakukan transaksi keuangan internasional dengan membeli atau menanyakan (permintaan) dan menjual atau memasok (menyediakan) dalam valuta asing atau valuta asing.

Sedangkan Salvatore (1997: 2) berpendapat, pasar valuta asing adalah pasar atau tempat bertemunya individu, bisnis, dan komunitas perbankan untuk

\footnotetext{
${ }^{8}$ Dewan Syari, A H Nasional, and Pasar Uang Antarbank, 'Pasar Uang Antarbank Berdasarkan Prinsip Syari'Ah', 4 (2002), 1-5.
} 
membeli dan menjual mata uang negara lain atau mata uang asing lainnya. Lain halnya Siamat (2001: 228), pasar valuta asing adalah suatu mekanisme dimana orang dapat mentransfer daya beli antar negara, memperoleh atau memberikan kredit untuk transaksi perdagangan internasional, dan meminimalkan risiko potensi kerugian akibat fluktuasi nilai tukar. Beberapa definisi di atas menunjukkan bahwa pasar valuta asing merupakan wahana atau wahana untuk memfasilitasi perdagangan dan investasi internasional.

Pemilihan dana pada pasar uang selalu berkaitan menggunakan pasar uang. Artinya bila kita hendak menginvestasikan uang kita pada pasar uang maka, kita akan selalu mempertimbangkan aktivitas yg terjadi pada pasar valas, demikian juga sebaliknya. Hal ini dilakukan buat memilih investasi mana yg paling menguntungkan pada pasar uang atau valas. Interaksi antara pasar uang \& valas ini sebagai lebih krusial jika jumlah dana yg terdapat pada jumlah akbar atau syarat ekonomi dalam waktu yg kurang baik. $^{9}$

Umumnya, ada beberapa peran pasar valas bagi pelaku pasar valas berikut macamnya:

1. Memiliki transfer daya beli. Transfer terebut sangat diperlukan dalam perdagangan internasional dan persetujuan jual beli modal yang melibatkan pihak-pihak yang berada di negara-negara yang biasanya menggunakan mata uang lain. Pada umumnya, meskipun suatu transaksi atau transaksi modal dalam mata uang lain, masing-masing pihak bersikeras menggunakan mata uangnya sendiri. Dengan demikian, pasar valuta asing menyediakan mekanisme untuk mentransfer daya beli.

2. Mempunyai layanan kredit. Dalam perdagangan internasional, pengiriman barang antar negara membutuhkan waktu, sehingga harus ada cara untuk membiayai barang tersebut selama pengiriman, termasuk setelah barang sampai di tempat tujuan. Mereka biasanya membutuhkan waktu sebelum dijual ke pelanggan. Pasar valuta asing menyediakan sumber kredit pihak

\footnotetext{
${ }^{9}$ Fakultas Ekonomi and Universitas Sebelas Maret, 'Perpustakaan.Uns.Ac.Id Digilib.Uns.Ac.Id', 2011.
} 
ketiga. Transaksi dapat dibiayai dengan menggunakan sarana khusus seperti bank underwriting dan letter of credit.

3. Adanya fasilitas untuk memitigasi risiko nilai tukar mata uang asing. Jika ada perdagangan antara kedua negara dan tidak ada risiko fluktuasi nilai tukar. Keduanya mengharapkan keuntungan dari kemungkinan risiko yang dinilai, seperti perubahan tajam dalam nilai tukar yang, dalam kondisi normal, mempengaruhi ukuran pengembalian yang diharapkan.

Pemain utama di pasar valuta asing tidak hanya bervariasi dalam ukuran operasi mereka, tetapi juga dalam tujuan dan metode penggunaan pasar ini. Khambata dan Ajami (Kuncoro, 1996:108), pelaku ekonomi yang utama dalam pasar valuta asing dapat digolongkan menjadi:

1. Perorangan. Seseorang memakai pasar valuta asing buat mempermudah aplikasi transfer investasi atau komersial yg terdorong sang kebutuhan usaha maupun pribadinya. Kebutuhan pribadi, contohnya seorang ingin mengirim sejumlah uang pada familinya pada luar negeri maka dia akan memanfaatkan pasar valuta asing buat memperoleh mata uang berdasarkan negara pada mana familinya tinggal. Sedangkan kebutuhan usaha ada jika seorang terlibat pada usaha internasional. Misalnya, importir individu memakai pasar valas buat memperoleh mata uang yg dibutuhkan buat membayar pada pemasok barangnya pada luar negeri. Mereka merupakan pengguna $\&$ pemasok valuta asing yg bersifat langsung.

2. Lembaga. Lembaga memainkan peran penting dalam pasar valuta asing karena permintaan valuta asing yang besar dan bervariasi. Perusahaan multinasional adalah pemain utama di pasar valuta asing yang perlu mentransfer sejumlah besar mata uang melintasi perbatasan dan mengubahnya dari satu mata uang ke mata uang lainnya. Lembaga keuangan yang melakukan investasi internasional juga berpartisipasi di pasar valuta asing, karena hal ini sering kali dapat menyebabkan perdagangan valuta asing yang agak besar karena Anda harus mengubah investasi multi-mata uang. Selain untuk memenuhi kebutuhan transaksi 
bisnis, baik individu maupun institusi memanfaatkan pasar valuta asing untuk mengurangi risiko dampak negatif fluktuasi nilai tukar.

3. Pialang Valas. Broker Forex adalah perantara yang menghubungkan dan menawarkan pihak yang membutuhkan Forex di pasar Forex. Mereka tidak memperdagangkan mata uang asing mereka sendiri dan tidak berpartisipasi dalam perdagangan yang sebenarnya. Salah satu aset utama broker adalah kepemilikan intelijen pasar. Pialang mengumpulkan berbagai peserta di pasar valas dan menjaga kerahasiaan dan anonimitas pelaku pasar. $^{10}$

Nilai tukar adalah perhitungan pertukaran antara dua mata uang dari jenis yang berbeda. Selama itu memotivasi orang untuk menukar mata uang, salah satu dari dua pertukaran perlu menggunakan mata uang yang dimiliki oleh yang lain. Pertukaran antara orang dan mata uang yang beredar di negara yang sama, misalnya emas dan perak, dan perak dan emas, sangat jelas. Hal ini dikarenakan biasanya negara-negara tersebut menggunakan sistem koin emas dan perak dan terdapat nilai tukar antara kedua mata uang tersebut. Nilai tukar ditentukan sesuai dengan harga pasar. Mengubah nilai tukar antara mata uang yang sama yang diterima oleh dua jenis negara yang berbeda tidak berisiko. Hal ini karena keadaan sama dengan perubahan harga barang tersebut.

Oleh karena itu, nilai tukar dapat berubah setelah harga barang di negara yang mengeluarkan mata uang berubah. Misalnya, jika tingkat harga agregat di satu negara naik relatif terhadap negara lain karena peningkatan jumlah uang yang beredar, nilai tukar antara kedua negara harus berubah. Oleh karena itu juga, nilai tukar mata uang asing suatu negara dengan kenaikan inflasi akan menurun.

Oleh karena itu, nilai tukar antara mata uang suatu negara dan negara asing bergantung pada hubungan antara mata uang asing dan nilai tukar komoditas negara tersebut. Misalnya, \$1USD sama dengan Rp. 14.300.00 di Indonesia.

Ini adalah money changer dan nilai tukar mata uang dari seluruh dunia. Oleh karena itu, pertukaran mata uang antar mata uang yang sejenis harus memiliki

${ }^{10}$ Anik Sudarismiati, ‘Analisa Pengaruh Tukar Rupiah', Jambsp, 5.1 (2008), 1-16. 
bobot dan jenis yang sama dan tidak berlebihan (misalnya Rp). 10.000.00 Rp. Di atas Rp 9.000,00. 1,000.00. Demikian pula pertukaran mata uang antar mata uang yang sejenis tidak boleh berbeda. Hukum Syariah adalah sama, jadi tidak berubah sama sekali. Sementara di sisi lain, pertukaran mata uang antara dua jenis yang berbeda dapat berlebihan atau seimbang, seperti menukar rupee dengan dolar dan emas dengan perak. Namun, keduanya harus diserahkan secara tunai (in kind). Tidak ada perbedaan antara devisa dalam negeri dan luar negeri dalam hal ini. Karena hukum Syariah adalah sama dan tidak berubah. Namun, jika aturan melebih-lebihkan sama, itu dilarang. Kebalikannya harus sama. baik berat maupun jenisnya. Karena mereka membesar-besarkan ini dalam konteks krisis ekonomi, dan dalam islam riba hukumnya haram. ${ }^{11}$

\footnotetext{
${ }^{11}$ Sarmedi, 'UAL BELI VALUTA ASING DALAM PERSPEKTIF HUKUM ISLAM', Ekonomi Dan Keuangan Islam, 01.02 (2021), 211-136.
} 


\section{BAB IV \\ PENUTUP}

\section{Kesimpulan}

Pasar keuangan jangka pendek berdasarkan prinsip syariah adalah transaksi keuangan jangka pendek (bebas bunga) yang dilakukan oleh pelaku pasar keuangan jangka pendek atau pelaku pasar keuangan jangka pendek. Karena pembelian sekuritas berumur pendek, transaksi hanya didasarkan pada kepercayaan. Satu-satunya pasar uang yang diperbolehkan adalah pasar uang yang tidak menggunakan sistem suku bunga, untuk menghindari riba dalam beras karena kerugian (risiko) bunga lebih besar daripada keuntungannya. (Mashraq) Ini. Juga karena Islam melarang jual beli uang sebagai komoditas atau spekulasi. Padahal, pasar uang syariah dan pasar uang tradisional memiliki fungsi yang sama, termasuk fungsi sebagai pengatur likuiditas. Ketika bank memiliki kelebihan likuiditas, dapat menginvestasikan dana menggunakan instrumen keuangan jangka pendek, dan ketika likuiditas tidak mencukupi, dapat menerbitkan produk yang dapat dijual untuk mendapatkan uang tunai.

\section{Saran}

Kami memahami bahwa ini jauh dari kata lengkap. Namun, kami ingin pembaca kami memahami apa yang kami jelaskan. Kritik dan saran sangat kami butuhkan untuk perbaikan artikel kami. 


\section{DAFTAR PUSTAKA}

Ekonomi, Fakultas, and Universitas Sebelas Maret, 'Perpustakaan.Uns.Ac.Id Digilib.Uns.Ac.Id', 2011

Ismawati, 'PASAR UANG DALAM PERSPEKTIF ISLAM', Manajemen Ide Dan Inspirasi, 3.1, 96-106

Muchtar, Evan Hamzah, and Siti Najma, 'APLIKASI SISTEM KEUANGAN SYARIAH PADA PASAR UANG', Asy-Syukriyyah, 20 (2019), 56

Nasution, Yenni Samri Julia, Pasar Uang Dan Pasar Modal : Suatu Pengantar, 2018

Prishardoyo, Bambang, 'Analisis Faktor-Faktor Yang Mempengaruhi Volume Transaksi Pasar Uang Antar Bank Di Indonesia Tahun 1983-2007', Jejak, 3.2 (2010), 123-31 <https://doi.org/10.15294/jejak.v3i2.4655>

Samsul, Samsul, Najamuddin Mara Hamid, and Hotman Guba Nasution, 'Sistem Pengendalian Inflasi Dalam Sistem Ekonomi Islam', Al-Azhar Journal of Islamic Economics, 1.1 (2019), 16-28 $<$ https://doi.org/10.37146/ajie.v1i1.10>

Sarmedi, 'UAL BELI VALUTA ASING DALAM PERSPEKTIF HUKUM ISLAM', Ekonomi Dan Keuangan Islam, 01.02 (2021), 211-136

Sudarismiati, Anik, ‘Analisa Pengaruh Tukar Rupiah', Jambsp, 5.1 (2008), 1-16

Syari, Dewan, A H Nasional, and Pasar Uang Antarbank, 'Pasar Uang Antarbank Berdasarkan Prinsip Syari’Ah', 4 (2002), 1-5

Wardiyah, Mia Lasmi, Manajemen Pasar Uang \& Pasar Modal (Bandung, 2011) 